\title{
EFFECT OF EDUCATION FUND, THE NUMBER OF INFRASTRUCTURE, HR EFFECTIVENESS OF TEACHER EDUCATION PROGRAM
}

\author{
Selfiani \\ Economics Faculty, University of Mathla'ul Anwar, Banten \\ selfianiselfi@gmail.com
}

\begin{abstract}
This study aims to determine the effect of education funds, the amount of infrastructure, human resources of teachers to the effectiveness of education programs. The population in this study is sepill provincial education in Indonesia in 2016. The sample amounted to 34 provinces with the observation of 34 local revenue balance. The observation is conducted for one year, in 2016. The Data used are secondary Data, among others derived from the income balance of the province in Indonesia, especially the vocational school is determined through purposive sampling. Data analysis was done by hypothesis tested by linear regression method. The results of this study indicate that funds educational, teaching personnel affect the effectiveness of educational programs, while the amount of infrastructure does not affect the effectiveness of educational programs.
\end{abstract}

Keywords: Education Fund, BOS, Total Infrastructure, Teaching Personnel, Education Program Effectiveness.

\section{INTRODUCTION}

Problems education is always interesting to be discussed. Whenever and wherever place, the problems of education always gets special attention for the others. Almost all educational problems as there is no end. The right solutions have always been coveted by various parties educationists and education providers in order that the condition of education in Indonesia is getting better and lead to satisfaction of all parties.
This is what happens when governments like confusion direction in finding the best solutions that can boost the quality of education in Indonesia. While the people themselves as well as connoisseurs actors can only stunned education without being able to do anything other than criticize it out the various measures taken by the government. It's not something responsive if we as actors once lovers can only criticize education without being able to do 
something for the fate of education in Indonesia or at least give proposals how the solution if it were appropriate to the current problems.

evidenced among other things by the data of UNESCO (2000) ranked on the Human Development Index (HDI), the composition of the level of achievement in education, health, and revenue per head which showed that its index of human development in Indonesia has declined. Of the 174 countries in the world, Indonesia ranks 102 (1996), 99th (1997), 105th (1998) and 109th (1999).

Then, according to the Research and Development (2003) that of 146 052 elementary schools in Indonesia, only eight schools who gained worldwide recognition in the category of The Primary Years Program (PYP). Of $20 \quad 918$ secondary schools in Indonesia was also only eight schools that gained worldwide recognition in the category of The Middle Years Program (MYP) and from the 8036 high school was only seven schools who gained worldwide recognition in the category of the Diploma Program (DP).

If we think and want to dig deeper, in fact any measures taken by the government's main objective is to promote education in Indonesia. Although the process and the reality in the field, the policy is to experience a variety of obstacles and bring up the pros and cons in the many ways, however, small things can bring thousands of speculation and opinion in the eyes of the public, especially complex and involves many aspects of life such as education. Of course the task
The quality of education in Indonesia is very alarming. This is

performed by the government is very heavy and vital.

Based on the description of the above background, it can be formulated issues to be addressed are:

1. Is the Education Fund has an influence on the Effectiveness of Education Program?

2. Is the amount of infrastructure has an influence on the Effectiveness of Education Program?

3. HR Teachers have an influence on the Effectiveness of Education Program?

Based on the problems formulated above, the purpose of this study is:

1. To analyze and assess the effect of the Education Fund Education Program Effectiveness

2. To analyze and assess the effect of Total Infrastructure against Education Program Effectiveness

3. To analyze and assess the effect of the Effectiveness of HR Teacher Education Program

The benefits of this research is to be obtained is intended for:

1. Theoretical benefits

This study is expected to be able to contribute bermannfaat for the development of science in the academic world, as well as 
developments in science to develop a model on the variables that have a relationship and influence are fund, the amount of infrastructure, tbsp teacher and the effectiveness of educational programs. Then the results of this research may find the concept or theory that is able to address the issues of academic conduct such studies in the research.

2. Practical benefits

In the world of practical research is expected to contribute in providing solutions to practical permalahan related topics, themes and issues that were examined in the study of education funding, the amount of infrastructure, faculty and Effectiveness tbsp education program. Then it is practically able to provide solutions in solving the problems faced by practitioners.

\section{LITERATURE REVIEW}

The quality of education in Indonesia is very alarming. This is evidenced among other things by the data of UNESCO (2000) ranked on the Human Development Index (HDI), the composition of the level of achievement in education, health, and revenue per head which showed that its index of human development in Indonesia has declined. Of the 174 countries in the world, Indonesia closely related to the theme of the study, the problem of variables in research concerning the education ranks 102 (1996), 99th (1997), 105th (1998) and 109th (1999).

According to the survey Consultant Political and Economic Risk (PERC), the quality of education in Indonesia ranks 12th of 12 countries in Asia. The data obtained from the World Economic Forum Sweden (2000), Indonesia has low competitiveness which only ranks 37th out of 57 countries surveyed across the globe. And according to the same survey, Indonesia predicated only as a follower, not a leader of technology from 53 countries around the world.

Then, according to the Research and Development (2003) that of 146 052 elementary schools in Indonesia, only eight schools who gained worldwide recognition in the category of The Primary Years $\begin{array}{lllll}\text { Program (PYP). } & \text { Of } & 20 & 918\end{array}$ secondary schools in Indonesia was also only eight schools that gained worldwide recognition in the category of The Middle Years Program (MYP) and from the 8036 high school was only seven schools who gained worldwide recognition in the category of the Diploma Program (DP).

In terms of achievement, September 15, 2004 United for Development Program (UNDP) has also announced the results of a study on human qualities simultaneously around the world through a report titled Development Report 2004. In this annual report Indonesia only 111th position dai 177 countries, 
In addition, there are many facts which show that the quality of education in Indonesia is very alarming. But these facts should be able to pump up our spirit as well as connoisseurs offender education to

There is a shortage we can summarize the global context concerning education curriculum. First, the curriculum in Indonesia are not emphasize the importance and ongoing studies in the archipelago insight. This is evidenced by the lack of attention to the educational institutions, especially the allocation of time subjects of Citizenship in the realization only came under the spotlight during the $2 \mathrm{~s} / \mathrm{d} 2.5$ hours per week.

This will impact on the lack of a spirit of nationalism of learners. This would harm the nation because when the students enter the workforce. Their main orientation may be more directed towards the material rather than member contributions to the state. improve the quality of education in Indonesia, and shoulder to shoulder with the government to overcome imbalances that caused the quality of education in Indonesia so badly

Second, the curriculum in Indonesia in terms of teaching us a less direct learners to later if it has passed the formal education to create something. This will form the personality of the consumer.

Factors Affecting the Quality of Education in Indonesia Increasingly lagging education of this nation from other nations should make us more motivated to improve itself. The number of education issues that arise increasingly complex with the growing age. The following will specifically discuss a number of factors that lead to low quality of education in Indonesia, namely: high cost of education, poor quality of infrastructure, and human resource teachers

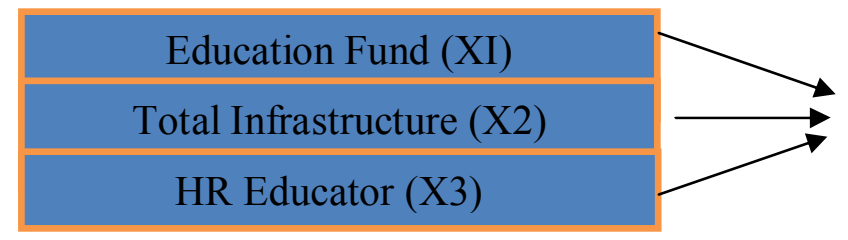

Effectiveness of Education Program

"The quality education is expensive". This phrase often appears to justify the high cost of education. The cost of education from kindergarten (kindergarten) to university (PT) makes the poor community have no other option but do not go to school.
Actually, if we compare with other countries to study abroad is much more expensive compared to the cost of our education. But why do people still think of the cost of education in Indonesia is very expensive? Of course it can happen 
given the state of our economy today.

HI : There is influence Among positive Relief Fund to Effectiveness

\section{Education programs}

educational institutions that do not have their own building, ownership and use of low learning media, as well as a library book is not complete. While not appropriate laboratory standards, inadequate use of information technology and so on.

Nana Fatah, an education expert Indonesian Education University (UPI) said about $60 \%$ of school buildings in Indonesia was heavily damaged. In West Java, damaged schools reached $50 \%$.

Data Research and Education Ministry (2003) for the SD units are institutions that accommodate 146 052 25,918,898 865258 students and has a classroom. Of all classrooms as much as 364440 or $42.12 \%$ in good condition, 299581 or $34.62 \%$ was slightly damaged, and as many as 201237 , or $23.26 \%$, were seriously damaged. A similar situation occurred in junior high school, junior high, high school and vocational school but the percentage is not the same.

H2: There is a positive influence between Total Infrastructure against Effectiveness of Education Program

State teachers in Indonesia was also concerned. Most teachers do not yet have sufficient professionalism to carry out their duties as mentioned in article 39 of Law No. 20/2003 are planning lessons, coaching, do care, conduct research and perform community service.
For infrastructure, a lot of educational institutions in Indonesia that is unfit for use. Many of the schools and colleges of our buildings destroyed, or even the still existing

Percentage of teachers according to the feasibility of teaching in the years 2002-2003 in various educational units is as follows: for a decent elementary teaching only $21.07 \%$ (domestic) and 28.94\% (private), for SMP $54.12 \%$ (domestic) and 60.99\% (private), for high school $65.29 \%$ (domestic) and $64.73 \%$ (private), as well as for proper vocational teaching $55.49 \%$ (domestic) and 58.26\% (private).

Although the teacher or teaching is not the only factor determining the success of education, but teaching is the central point of education and qualifications. As reflecting the quality, teaching staff has a large stake in the quality of education becomes the teacher's welfare. Decreasing affect its role in making the quality of education in Indonesia. Based on the survey FGII (Gur Federation of Independent Indonesia) in mid-2005, ideally a teacher receives a monthly salary of Rp.3,000,000.00. Now the average income per month teacher Rp.1.500.000,00. USD assistant teachers. $460.000,00$ and part time teachers in private schools on average Rp.10,000.00/hour. With revenue as it is, frankly, many teachers who do a side job. There is teaching again at another school, tutor in the afternoon, motorcycle taxis, traders boiled noodles, booksellers / LKS, the mobile phone dealers, etc. (Republika, July 13th, 2005). 
Additionally gap in private and public teachers into other problems that arise. In the private education environment, teachers' welfare issues still difficult to achieve the ideal level. As many as $70 \%$ of the 403

teacher become influential on the quality of education in Indonesia? It is an important and influential if the welfare of the teachers have not been met, will likely be difficult for teachers to deliver instructional materials to students with optimal because it could be their motivation to transfer knowledge to be reduced.

\section{METHODOLOGY}

\subsection{Samples}

The population in this study is Seprovinsi Education in Indonesia in 2016, Mechanical take research samples using purposive sampling that one of the non-random sampling sampling technique in which researchers determine the sampling by defining specific characteristics to suit the purpose of research that is expected to answer the research problems. Based on the sampling purposive explanation, there are two very important things in using the sampling technique, which is nonrandom sampling and define specific characteristics to the purpose of research by the researchers themselves. Sampling in this study using seprovinsi education in Indonesia.

The sampling method used in this research is purposive sampling sampling technique with consideration or with certain criteria. The conditions or criteria specified in this study, namely: private universities in West Java and Banten are not able to adjust the welfare of lecturers in accordance with the mandate of Law Teachers and Lecturers (Mind, January 9th, 2006). Why is the welfare of the And educators concentration was more directed towards how to meet their own needs.

\section{H3 : There is a positive influence between HR Educator of the Program Effectiveness Education}

1. Penididikan Seprovinsi in Indonesia in 2016.

2. Education levels of SMK 2016 period.

Secondary data used in this study was obtained from the Balance of Revenue in the Ministry of Education and Culture website.

\subsection{Variables}

\subsubsection{Effectiveness of Education Program (Y)}

Figures CMS Pure partisisi

Source: PDSPK 2016

\subsubsection{Education Fund (X1)}

For this problem, the government has launched a program of BOS (Student operation funds). With BOS, education in Indonesia can be enjoyed by all people (though still up SMP). However, today has many institutions that provide scholarships to students who excel as well as for students who cannot afford. Given this, the cooperation between the government and the parties that organized it can increase the motivation to learn from the students themselves. In addition, the program 
is certainly evidence of the realization and the seriousness of the government so that all people can enjoy education, then the measurement wear Operational Support Students (BOS)

Source: Bureau of PKLN 2016

quality education with such favorable conditions. Then the measurement of this variable isclassroom conditions that exist in the Balance Sheet of Revenue.

Source: PDSPK 2016

\subsubsection{HR Educator (X3)}

The government began active in the provision of supplies, counseling, workshop, and so on to improve the quality of teachers in Indonesia. Proven at this time all Civil Servants who have been or are being taught,

\section{ANALYSIS AND DISCUSSION}

\subsection{Data Description}

In this study population used is Seprovinsi Education in Indonesia in 2016. The data in this study were obtained from the official website of the ministry of education and culture kemendikbud.go.id). The data in this study using Eviews program version 9 and Microsoft Excel 2007. The processed data obtained from the income account in the area of Indonesia. The sampling technique in this study using purposive sampling technique that is based on the established criteria. Sampling in this

\subsubsection{Total Infrastructure (X2)}

The government annually has attempted to increase the budget for education. And of course the goal is for all Indonesian people can enjoy

to be titled S1. This means, inevitably for teachers who hold a diploma must take further education to obtain a Bachelor's degree and automatically, they will gain more knowledge as well. And hopefully with this policy, teachers in Indonesia can be further increased quality.

Then the measurement of these variables is the qualification of teachers in the Balance Sheet of Revenue.

Source: PDSPK 2016

case been carefully until relevant to the specific criteria as discussed

in the methodology. So there are 34 provinces in Indonesia.

\subsection{Data Analysis Method}

In analyzing this data using linear regression.

Descriptive statistics

Descriptive statistics were used to determine the characteristics of each of the samples used in the study without linking and comparing it with other variables. Descriptive statistical value of each variable of this study are as follows: 


\begin{tabular}{lcccc}
\multicolumn{1}{c}{$\begin{array}{c}\text { EFEKTIFITAS_P } \\
\text { ROGRAM_PEN }\end{array}$} & \multicolumn{3}{c}{ JUMLAH_INFR SDM_PENGAJA } \\
& D & BOSS & ASTRUKTUR & R \\
mean & 61.47353 & 1282.789 & 1448.939 & 92.54412 \\
median & 61.30000 & 635.4150 & 866.5000 & 92.85000 \\
maximum & 73.10000 & 7589.660 & 8930.000 & 95.80000 \\
Minimum & 37.70000 & 128.9400 & 10.92400 & 87.90000 \\
Std. Dev. & 7.447770 & 1644.906 & 1923.366 & 2.003964 \\
skewness & -0.752417 & 2.528534 & 2.730587 & -0.494361 \\
kurtosis & 4.177838 & 8.904500 & 10.09786 & 2.502111 \\
& & & & \\
Jarque-Bera & 5.173424 & 85.61918 & 113.6224 & 1.736075 \\
probability & 0.075267 & 0.000000 & 0.000000 & 0.419775 \\
& & & & \\
Sum & 2090.100 & 43614.83 & 49263.92 & 3146.500 \\
Sum Sq. Dev. & 1830.486 & 89288629 & $1.22 \mathrm{E}+08$ & 132.5238 \\
Observations & 34 & 34 & & 34
\end{tabular}

Source: Processed Data Eviews 9

Based on the above research variables descriptive statistics as follows:

a. Education Fund (X1)

The percentage of funds pedidikan the effectiveness of educational programs have a minimum value of 128.9400 in northern Kalimantan province in 2016. And the maximum value of 7589.220 on west Java province in 2016. Overall gained an average of 1282.789 and standard deviations for the variables 1644.906.

b. Total Infrastructure (X2)

The percentage amount of the infrastructure of the effectiveness of educational programs have a minimum value of 10.92400 in west Java province in 2016. And the maximum value of 8930 in Central Java province in 2016. Overall gained an average of 1448.939 and standard deviation of variables for 1923366.

c. HR Educator (X3)
Percentage of HR Educator of the effectiveness of educational programs have a minimum value of 87.9 in the provinces of North Maluku in 2016. And the maximum value of 95.8 in west Sumatra province in 2016. Overall gained an average of 92544 and a standard deviation of 2.0039 variables.

\subsection{Test assumptions and Quality Research Instruments}

Normality test

The decision whether or not the residuals are normally distributed simply by comparing the value of probability JB (Jarque-Bera) is calculated with an alpha level of 0.05 $(5 \%)$. If Prob. JB count is greater than 0.05 , it can be concluded that the residuals are normally distributed and conversely, if the value is less then not enough evidence to suggest that the residuals are normally distributed. 


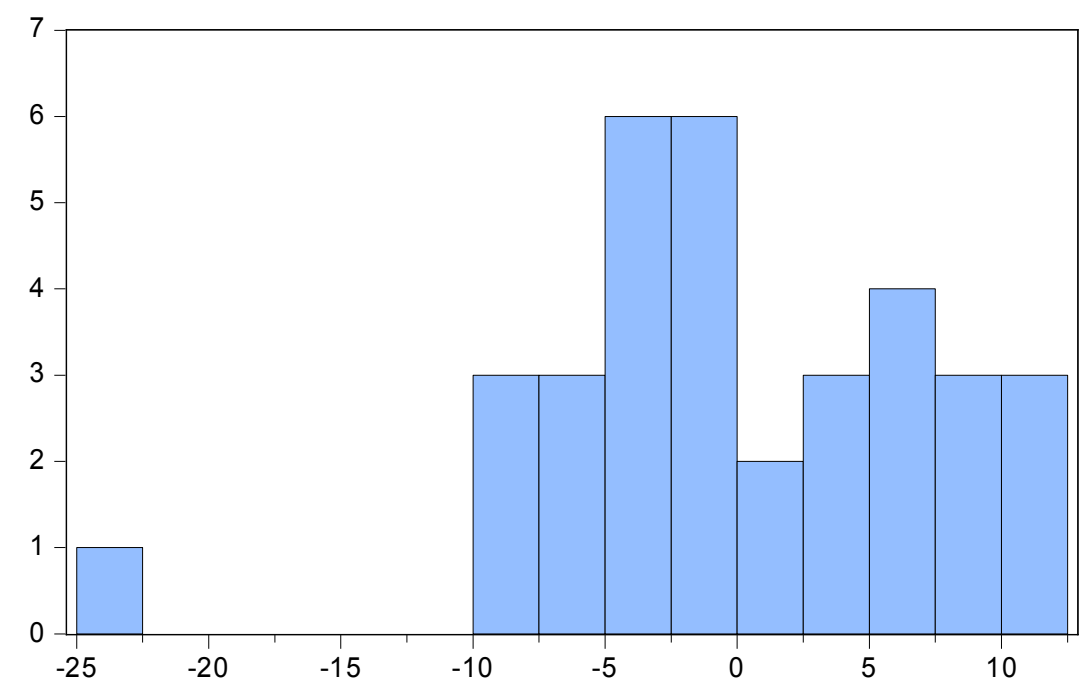

Series: Residuals

Sample 134

Observations 34

Mean

$-8.93 e-15$

Median

$-0.413677$

Maximum

11.43560

Minimum $\quad-23.84189$

Std. Dev. $\quad 7.380100$

Skewness $\quad-0.691749$

Kurtosis

4.398024

Jarque-Bera $\quad 5.480429$

Probability

0.064557

Source: Processed Data Eviews 9

From the above data Value Prob. JB count equal to $0.064557>0.05$ so that it can be concluded that the residuals are normally distributed,

\subsection{Test Multicollinearity}

To detect whether the independent variables that are used have a high colinearity or not, by using the which means the classical assumption of normality has been met.

Variance Inflation Factor (VIF). The results of analysis by using VIF can be seen in the table below:

Variance Inflation Factors

Date: 12/13/17 Time: 23:55

Sample: 134

Included observations: 34

\begin{tabular}{cccc}
\hline \hline variable & $\begin{array}{c}\text { Coefficient } \\
\text { Variance }\end{array}$ & $\begin{array}{c}\text { Uncentered } \\
\text { VIF }\end{array}$ & $\begin{array}{c}\text { Centered } \\
\text { VIF }\end{array}$ \\
\hline \hline C & 4363.157 & 2476.068 & NA \\
BOSS & $4.64 \mathrm{E}-10$ & 1.053023 & 1.014394 \\
JUMLAH_INFRASTRUK & & & \\
TUR & $5.61 \mathrm{E}-07$ & 1.810047 & 1.142194 \\
SDM_PENGAJAR & 0.515282 & 2505.544 & 1.139782 \\
\hline \hline
\end{tabular}

In the above table the value of Tolerance (TOL) ranges between 0 and 1 , and if TOL $=0$, then there is a high and perfect collinearity between independent variables while the default SPSS for tolerance figure is
0.0001. From table above, Value Tolerance (TOL) for all independent variables in this study is greater than 0.10 if greater than 0.10 then there is no multicollinearity in the regression model were used. Value Variance 
Inflation Factor (VIF) for all independent variables in this study is less than 10, if VIF is less than 10 then there is no multicollinearity. Thus, based on the results of analysis

\subsection{Autocorrelation Test}

Test of autocorrelation aims to determine the correlation between residual factor in period $t$ and period $\mathrm{t}-1$ in the regression model. This problem arises because the residual is not free from one observation to by using Tolerance (TOL) and Variance Inflation Factor (VIF), it can be detected that there is no multicollinearity.

another observation. A good regression model is a regression that is free of autocorrelation. To determine whether there is autocorrelation in a regression model.

Breusch-Godfrey Serial Correlation LM Test:

\begin{tabular}{llll}
\hline \hline F-statistic & 0.304867 & Prob. F (2,28) & 0.7396 \\
Obs * R-squared & 0.724612 & Prob. Chi-Square (2) & 0.6961 \\
\hline \hline
\end{tabular}

Test Equation:

Dependent Variable: Resid

Method: Least Squares

Date: 12/13/17 Time: 23:57

Sample: 134

Included observations: 34

Presample missing value lagged residuals set to zero.

\begin{tabular}{crlrr}
\hline \multicolumn{1}{c}{ variable } & coefficient & \multicolumn{1}{c}{ Std. Error } & t-Statistic & Prob. \\
\hline \hline C & -8.494152 & 69.19115 & -0.122764 & 0.9032 \\
BOSS & $3.83 \mathrm{E}-06$ & $2.27 \mathrm{E}-05$ & 0.168913 & 0.8671 \\
\hline \hline JUMLAH_INFRASTRUKTUR & $9.37 \mathrm{E}-05$ & 0.000776 & 0.120704 & 0.9048 \\
SDM_PENGAJAR & 0.090088 & 0.751349 & 0.119902 & 0.9054 \\
Resid (-1) & 0.123429 & 0.192996 & 0.639542 & 0.5277 \\
Resid (-2) & 0.080774 & 0.199475 & 0.404931 & 0.6886 \\
\hline \hline R-squared & 0.021312 & Mean dependent var & $-8.93 \mathrm{E}-15$ \\
Adjusted R-squared & -0.153454 & SD dependent var & 7.380100 \\
SE of regression & 7.926150 & Akaike information criterion & 7.136997 \\
Sum squared resid & 1759.068 & Schwarz criterion & 7.406355 \\
Log likelihood & -115.3290 & Hannan-Quinn criter. & 7.228856 \\
F-statistic & 0.121947 & Durbin-Watson stat & 1.923066 \\
Prob (F-statistic) & 0.986354 & & \\
\hline \hline \hline
\end{tabular}

Value Prob. F $(2,28) \neq$ amounted to 0.7396 can also be referred to as a probability value of $F$ count. Value Prob. F count larger than the alpha level of $0.05(5 \%)$ so that, by testing hypotheses, H0 is accepted which means no autocorrelation. Conversely, if the value of Prob. F count is smaller than 0.05 , it can be concluded autocorrelation. 


\subsection{Test Heteroskedasticity}

This test aims to test whether the regression model inequality variance of residuals of an observation to another observation, To detect the presence or absence Heteroskedasticity is looking the prob. Chi-square

Heteroskedasticity Test: Breusch-Pagan-Godfrey

\begin{tabular}{llll}
\hline \hline F-statistic & 0.432640 & Prob. F (3,30) & 0.7312 \\
Obs * R-squared & 1.409975 & Prob. Chi-Square (3) & 0.7032 \\
Scaled explained SS & 2.170671 & Prob. Chi-Square (3) & 0.5377 \\
\hline \hline
\end{tabular}

Value Prob. of F count and ChiSquare test bigger than an alpha level of 0.05 , it can be concluded not happen heteroskedastisity on the model.

All the classical assumption in (log-linear models) have been met, so that the model is more feasible to use to explain the influence of the independent variable funding for education, infrastructure and the number of tablespoons of the effectiveness of teacher education programs.

Dependent Variable: EFEKTIFITAS_PROGRAM_PEND

\subsection{Test coefficient of determination}

R2 value indicates how large a proportion of the total variation in the dependent variable (dependent) can be explained by the explanatory variables (independent). The higher the value of $R 2$, the greater the proportion of the total variation in the dependent variable (dependent) can be explained by the independent variable. R2 shows how much variation explanatory variables (independent) affects the variation of the dependent variable (dependent).

Method: Least Squares

Date: 12/13/17 Time: 22:49

Sample: 134

Included observations: 34

\begin{tabular}{lrlrr}
\hline \hline \multicolumn{1}{c}{ variable } & coefficient & Std. Error & t-Statistic & Prob. \\
\hline \hline C & 14.58127 & 66.05420 & 0.220747 & 0.8268 \\
BOSS & $2.28 \mathrm{E}-06$ & $2.16 \mathrm{E}-05$ & 0.105851 & 0.0164 \\
JUMLAH_INFRASTRUKTUR & $-6.63 \mathrm{E}-05$ & 0.000749 & -0.088616 & 0.9300 \\
SDM_PENGAJAR & 0.507442 & 0.717831 & 0.706910 & 0.0485 \\
\hline \hline R-squared & 0.018089 & Mean dependent var & 61.47353 \\
Adjusted R-squared & -0.080102 & SD dependent var & 7.447770 \\
SE of regression & 7.740314 & Akaike information criterion & 7.040893 \\
Sum squared resid & 1797.374 & Schwarz criterion & 7.220464 \\
Log likelihood & -115.6952 & Hannan-Quinn criter. & 7.102132 \\
F-statistic & 0.184226 & Durbin-Watson stat & 1.727706 \\
Prob (F-statistic) & 0.906283 & & \\
\hline \hline \hline
\end{tabular}

Source: Processed Data Eviews 9

From the table above can be explained results of multiple regression analysis of R-Square is 0.018089 . Value which means that 
there is a contribution of $1.8089 \%$ variable education funds, the amount of infrastructure and faculty tablespoons in predicting the

\subsection{Hypothesis test $T$}

Individual parameter significance test, also called the $t$ statistical test is a test used to see the influence of the independent variables partially on the dependent variable. The test is effectiveness of educational programs while the remaining $98.191 \%$ is explained by other variables outside the model studied.

performed by multiple linear regression test at $95 \%$ confidence level and 5\% error in the analysis. Here are the results of the calculation of the $t$ value and the level of significance in this study:

\begin{tabular}{|c|c|c|c|c|}
\hline variable & coefficient & Std. Error & t-Statistic & Prob. \\
\hline $\mathrm{C}$ & 14.58127 & 66.05420 & 0.220747 & 0.8268 \\
\hline BOSS & $2.28 \mathrm{E}-06$ & $2.16 \mathrm{E}-05$ & 0.105851 & 0.0164 \\
\hline JUMLAH_INFRASTRUKTUR & $-6.63 \mathrm{E}-05$ & 0.000749 & -0.088616 & 0.9300 \\
\hline SDM_PENGAJAR & 0.507442 & 0.717831 & 0.706910 & 0.0485 \\
\hline R-squared & 0.018089 & \multicolumn{2}{|c|}{ Mean dependent var } & 61.47353 \\
\hline Adjusted R-squared & -0.080102 & \multicolumn{2}{|c|}{ SD dependent var } & 7.447770 \\
\hline $\mathrm{SE}$ of regression & 7.740314 & \multicolumn{2}{|c|}{ Akaike information criterion } & 7.040893 \\
\hline Sum squared resid & 1797.374 & \multicolumn{2}{|c|}{ Schwarz criterion } & 7.220464 \\
\hline Log likelihood & -115.6952 & \multicolumn{2}{|c|}{ Hannan-Quinn criter. } & 7.102132 \\
\hline F-statistic & 0.184226 & \multicolumn{2}{|c|}{ Durbin-Watson stat } & 1.727706 \\
\hline Prob (F-statistic) & 0.906283 & & & \\
\hline
\end{tabular}

Source: Processed Data Eviews 9

\section{1) Education Fund}

From the table above can be seen the influence of variables on the effectiveness of education fund education programs for statistical $t$ value $0.0164<0.05$. This means that education funding affect the educational programs statistic $t$ value of

$0.9300>0.05$. This means that the amount of the infrastructure does not affect the effectiveness of education programs Thus the second hypothesis $(\mathrm{H} 2)$ is rejected. effectiveness of educational programs. Thus the first hypothesis (H1) is accepted.

2) Number of Infrastructure

From the table above can be seen the effect of a variable number of the infrastructure of the effectiveness of 3) HR Educator

From the table above it can be seen the effect of variable HR Educator of the effectiveness of educational programs statistic $t$ value $0.0485<0.05$. This means that HR Educator affect the effectiveness of 
educational programs. Thus the third

\section{CONCLUSIONS}

1. The education fund (X1) affect the effectiveness of education programs, so that the hypothesis that has been formulated in accordance with the results of the study, thus $\mathrm{H} 1$ accepted In accordance with the analysis results concluded that increases in education funding affect the effectiveness of educational programs. The results of this study indicate that education funds taken into account in determining the effectiveness of educational programs.

2. The number of infrastructure (X2) does not affect the effectiveness of education programs, so that the hypothesis that has been formulated not in accordance with the results of the study, thus $\mathrm{H} 2$ rejected. In accordance with the results of the analysis concluded that the amount

\section{REFERENCES}

Blancahrd, Olivier (2017), Macro Economics, Seventh Edition, Boston, Pearson, pp. 453 - 496

Lam, Newman MK (2000), Government Intervention in the Economy: A ComparativeAnalysisofSinga poreandHongKong, Public Administration and Development 20 (5): 397421.

Khan, Salman and Pierre Batteau (2012), "Government intervention in Russian bourse: a case of financial contagion", Journal of hypothesis (H3) is accepted.

of the infrastructure does not affect the effectiveness of educational programs. The results of this study indicate that the amount of infrastructure is not taken into account in determining the effectiveness of educational programs.

3. The SDM faculty (X3) influence on the effectiveness of educational programs, so that the hypothesis that has been formulated in accordance with the results of the study, thus accepted H3 accordance with the results of the analysis concluded that the increase in human resources influence the effectiveness of teacher education programs. The results of this study indicate that human resources accounted for in determining the effectiveness of teacher education programs.

Financial Economic Policy, Vol. 4 Iss: 4, pp.320 - 339

Manullang (2008), Basic - Basic management, Yogyakarta, Indonesia Ghalia Nitisemito, Alex S (2008), Personnel Management, Second Edition, Yogyakarta, Indonesia Ghalia

Riyanto, Bambang (2008), Basic Basic Company Spending, Yogyakarta, GPFE 